\title{
The Endangered Species Act and Ursine Usurpations: A Grizzly Tale of Two Takings
}

\author{
Geoffrey L. Harrison $\dagger$
}

[W]ith respect to any endangered species ... it is unlawful for any person ... to take any such species ....

... nor shall private property be taken for public use, without just compensation. ${ }^{2}$

In an attempt to reverse the trend toward species extinction, Congress enacted the Endangered Species Act ("ESA") in 1973." The ESA declares it illegal to "harass, harm, pursue, hunt, shoot, wound, kill, trap, capture, or collect" any "endangered species." The ESA's broad prohibition against almost any conduct-whether intentional or accidental - that interferes with the activities of an endangered species reflects Congress's considerable concern with species preservation. In its sole pronouncement on the social value of the ESA, the Supreme Court generously appraised Congress's commitment to the preservation of endangered species. In Tennessee Valley Authority $v$ Hill, the Court found that the ESA's structure and legislative history demonstrated conclusively that Congress intended "to halt and reverse the trend toward species extinction, whatever the cost."' Congress considered the goal of

$\dagger$ B.A., B.S. 1989, The University of Pennsylvania; J.D. Candidate 1992, The University of Chicago.

16 USC § 1538(a)(1)(B) (1988).

2 US Const, Amend V.

3 Endangered Species Act of 1973, Pub L No 93-205, 87 Stat 884, codified as amended at 16 USC $\S \S 1531-1544$ (1988).

1 16 USC $\$ \S 1538(a)(1)(B)$ and 1532(19). The Secretary of the Interior determines which species are "endangered" pursuant to the detailed procedures outlined in 16 USC § 1533.

- 437 US 153, 184 (1978) (affirming order enjoining completion of a dam in order to preserve snail darters, an endangered species of perch) (emphasis added). See also George Cameron Coggins, Conserving Wildlife Resources: An Overview of the Endangered Species Act of 1973, 51 ND L Rev 315, 321 (1975) (Congress was willing "to devote whatever effort and resources were necessary to avoid further diminution of ... wildlife resources"). 
species preservation to be of "incalculable" value, exceeding the loss of any sum certain, even $\$ 100$ million. $^{\circ}$

Christy $v \mathrm{Hodel}^{7}$ presents an extreme but otherwise paradigmatic case with which this Comment is concerned. In Christy, the plaintiff shot and killed a grizzly bear-an endangered species $^{8}$ - while the grizzly preyed upon some of plaintiff's sheep. ${ }^{9}$ The plaintiff previously had reported similar ursine encroachments to the United States Fish and Wildlife Service, which had taken unsuccessful corrective action. ${ }^{10}$ The United States Department of the Interior fined the rancher $\$ 3,000$ for violating the ESA. ${ }^{11}$ The plaintiff then brought suit against the Secretary of the Interior to permanently enjoin enforcement of the ESA and to recover just compensation. The plaintiff argued that by compelling private citizens to tolerate the destruction of their property by endangered species, the ESA effected an unconstitutional "taking" of private property, violating the Fifth Amendment's Takings Clause. ${ }^{12}$ Concluding that it was the grizzly bears, and not the government, that took plaintiff's property, the Ninth Circuit affirmed the district court's entry of summary judgment in favor of the Secretary of the Interior. ${ }^{13}$

This Comment argues that the Takings Clause requires that compensation be paid to private citizens who, but for the ESA, could have prevented property damage or destruction wrought by

- Hill, 437 US at 187-88. See also Report of the House Committee on Merchant Marine and Fisheries, HR Rep No 93-412, 93d Cong, 1st Sess 4-5 (1973) ("it is in the best interests of mankind to minimize the losses of genetic variations"). For a discussion of whether the federal government should continue to spend considerable funds to safeguard every endangered species, see Lance D. Wood, On Protecting an Endangered Statute: The Endangered Species Act of 1973, 37 Fed Bar J 25, 32-39 (1978).

7857 F2d 1324 (9th Cir 1988), cert denied as Christy v Lujan, 490 US 1114 (1989).

- Grizzly bears are included in the Secretary of the Interior's list of endangered species. 50 CFR § 17.11(h) (1989), compiled pursuant to 16 USC $\S 1533$. The regulations expressly prohibit the "taking" of grizzly bears, except in certain circumstances inapplicable to Christy. Id at $\S 17.40(\mathrm{~b})$. For a complete list of endangered and threatened species, see 50 CFR § 17.11 (April 15, 1990).

- Even if the plaintiff had tried to frighten the bear away, rather than kill it, the ESA would still have imposed liability. The ESA declares it unlawful to "harass" protected species. 16 USC $\S \S 1538(a)(1)(B)$ and 1532(19). In fact, plaintiff's employee had, "with limited success," tried to frighten previous bears away by firing gun shots into the air and building fires. Christy, 857 F2d at 1326.

10 Id at 1326. A trapper employed by the United States Fish and Wildlife Service had "set snares in an attempt to capture the bears." Id.

11 Id at 1327. An administrative law judge subsequently reduced the amount of the fine to $\$ 2,500$. Id.

12 Id at 1334.

1s Id at 1335,1337 . By the evening on which plaintiff killed the grizzly bear, he had lost "approximately twenty sheep, worth at least $\$ 1200[] "$ to prior ursine predations. Plaintiff "lost a total of 84 sheep to the bears" before he removed the sheep. Id at 1326. 
the predations of governmentally protected endangered species. ${ }^{14}$ Section I explores and ultimately rejects the use of a defense-ofproperty defense to prosecutions under the ESA. The ESA's criminal provisions must be coupled with Takings Clause compensation to construct a legal regime that satisfies competing public and private interests. Section II lays the foundation for the ESA analysis by examining the Supreme Court's two doctrinal approaches to takings: per se and regulatory takings. Section III then applies the Supreme Court's takings analysis to the paradigmatic ESA case. Contrary to the holdings of recent state and federal court decisions, existing takings jurisprudence entitles ESA plaintiffs to compensation from the government. Finally, Section IV considers the incentive effects of awarding Takings Clause compensation to ESA plaintiffs. Compensation payments cure the ESA's constitutional infirmity while preserving the ESA's economically efficient species preservation scheme. This Comment concludes that the Takings Clause requires the government to pay compensation to private citizens who suffer property loss by complying with the ESA's species protection provisions.

\section{Criminal Law: A Faulty Approach}

As part of its enforcement scheme, the ESA expressly criminalizes knowing violations of its prohibitory provisions. ${ }^{15} \mathrm{~A}$ principal prohibition is the "taking" of endangered species, broadly defined to include even attempts to "harass, harm, pursue, hunt, shoot, wound, kill, trap, capture, or collect" such animals. ${ }^{16}$ Thus, a private citizen who, in almost any way, interferes with an endangered species may be subject to prosecution under the ESA. The ESA's criminal penalties effectively promote the public interest by deterring harmful interference with endangered species. In

14 Other federal species preservation statutes that also lack defense-of-property defenses to their prohibitions include: Wild Free-Roaming Horses and Burros Act, Pub $L$ No 92-195, 85 Stat 649 (1971), codified at 16 USC $\$$ 1331-1340 (1988); Marine Mammal Protection Act of 1972, Pub L No 92-522, 86 Stat 1027, codified at 16 USC $\S$ 1361-1407 (1988); Migratory Bird Treaty Act, 40 Stat 755 (1918), codified as amended at 16 USC \$\$ 703-712 (1988); Bald and Golden Eagle Protection Act, 54 Stat 250 (1940), codified at 16 USC \$§ 668-668d (1988). Although the Takings Clause arguments apply equally to all of these species preservation acts, for simplicity this Comment refers only to the ESA.

This Comment does not consider takings claims arising under the ESA's prohibition against interstate commerce involving endangered species. 16 USC § 1538(a)(1)(E). For a discussion of this provision and the illegality of commercial interstate transportation of endangered species, see United States v Kepler, 531 F2d 796 (6th Cir 1976).

15 16 USC \& 1540(b).

16 16 USC $\S \S 1538(a)(1)(B)$ and 1532(19). 
so doing, however, the penalties make no allowance for private property interests.

\section{A. Defense-of-Property Defenses}

One obvious way to recognize an individual's interest in property would be to accord ESA defendants a justification defense for "taking" an endangered species in defense of property. Some state courts, interpreting state constitutions and freed from the constraints of the ESA, have been quite receptive to such defenses to prosecution under state game laws. Typically, these courts reason that a private citizen's interest in preserving private property suffciently justifies violations of state game protection statutes. The Montana Supreme Court, for example, concluded that a private citizen's right under the state constitution to protect property provided a complete defense to prosecution for killing an elk out of season in violation of state law, despite the lack of a statutory exception. ${ }^{17}$

Similarly, the Wyoming Supreme Court reversed a conviction of a person who, to protect his property, had killed a moose out of season. ${ }^{18}$ The court concluded that the state legislature lacked the authority to enact a statute depriving individuals of the right to defend their property from the "depredations of wild animals."19 In addition to such cases, some state species preservation statutes explicitly provide a defense-of-property defense to prosecutions under the statutes. ${ }^{20}$

Federal courts, however, have consistently refused to carve out a defense-of-property defense to prosecutions for violations of the ESA and similar statutes. ${ }^{21}$ There are several reasons for their re-

17 State $v$ Rathbone, 110 Mont 225, 100 P2d 86, 90-91 (1940). The court reasoned that because defense-of-property was a permitted defense for homicide prosecutions, it applied a fortiori to unlawful killing of animals. Id at 91. The court further imposed a "reasonableness" standard by which the jury should evaluate defendant's conduct. Id at 93.

18 Cross $v$ State, 370 P2d 371, 378 (Wyo 1962).

19 Id at 374. See also State $v$ Ward, 170 Iowa 185, 152 NW 501, 502 (1915) (killing deer justified if "reasonably necessary" to prevent "substantial injury" to property); 38 CJS Game $\S 10(a)$ at 12 (1943) ("Legal justification may always be interposed as a defense by a person charged with killing a wild animal contrary to law.") (emphasis in original); 35 Am Jur $2 \mathrm{~d}$ Fish and Game $\$ 37$ at 678 (1967) ("a statute forbidding the killing of game under penalty does not apply to a killing which is necessary for the defense of person or property").

${ }^{20} \mathrm{See}$, for example, the Alaska Board of Fish and Game's enactment, 5 AAC 81.375 (pre-1984), providing that "Nothing in this chapter prohibits a person from taking game in defense of life or property. . . . (c) As used in this section, 'property' is limited to . . . (3) domesticated animals."

${ }^{21}$ See Christy, 857 F2d at 1334-35; United States v Darst, 726 F Supp 286, 288 (D Kan 
fusal. First, the ESA does not contain an express defense-of-property exception to its prohibitions. It does, however, contain an exception for a good faith belief that the act was necessary for selfdefense or defense of others. ${ }^{22}$ The omission of a defense-of-property provision from the ESA suggests that it is not a proper defense to ESA prosecutions. As a matter of statutory interpretation, where certain exceptions are enumerated, no others are cognizable. It would have been easy for Congress to include an exception to ESA prosecutions for violations in defense-of-property had it so intended.

Second, unlike state courts interpreting their own constitutions, federal courts have been unwilling to imply a defense-ofproperty defense when interpreting the United States Constitution. The clearest explanation for the difference in treatment between state and federal courts is that a number of state constitutions expressly recognize an individual's right to defense of property, ${ }^{23}$ while the federal Constitution does not. ${ }^{24}$ Under this view, state courts have a constitutional mandate to uphold a citizen's right to defend property. The federal courts have not found similar authority in the U.S. Constitution.

\section{B. Reconciling Public and Private Concerns}

A legal rule that gives no effect to defense-of-property justifcations elevates the public's interest over that of private citizens. Though such elevation is common, it is not compelled; legislation

1989) (protection of property not a defense to prosecution under Migratory Bird Treaty Act).

2216 USC \& $1540(\mathrm{~b})(3)$. A similar defense to civil actions is found in 16 USC $\S$ $1540(\mathrm{a})(3)$.

23 See, for example, Fla Const, Art XVI, § 29; Iowa Const, Art I, § 1; Mont Const, Art II, § 3; Wash Const, Art I, § 16. Illustratively, the Iowa Constitution provides: "All men are, by nature, free and equal, and have certain inalienable rights-among which are those of enjoying and defending life and liberty, acquiring, possessing and protecting property, and pursuing and obtaining safety and happiness" (emphasis added).

24 The express language of the Constitution provides only that "no person shall be ... deprived of life, liberty, or property without due process of law." US Const, Amend V, cl 4. Some have argued that the Constitution may be read to include a right to defense of property. See Christy v Lujan, 490 US 1114, 1114 (1989) (White dissenting from denial of cert); Beard v United States, 158 US 550, 555 (1895). In fact, the Wyoming Supreme Court interpreted identical language in its state constitution to include a defense-of-property defense. Cross, $370 \mathrm{P} 2 \mathrm{~d}$ at 378 . While it is plausible to argue that citizens have a fundamental/constitutional right to protect their property, the Supreme Court has been reluctant to imply new fundamental rights. See Cruzan v Director, Missouri Dep't of Health, 110 S Ct 2841 (1990); Bowers v Hardwick, 478 US 186, 194 (1986). Further discussion of this potential right is beyond the scope of this Comment. 
like the ESA should be aimed at reconciling these competing interests. ${ }^{25}$ The result reached in Christy fails to do so, and is evidence that the ESA's solution is out of proportion to its goal. The public suffered because fining the plaintiff did little to resurrect the dead grizzly bear. The private citizen suffered because, while the sheep were preserved, he was compelled to pay a large fine. The optimal legal rule would satisfy the interests of both the public and the private property owner. The public values species preservation, while private parties value property protection. Currently, the individual whose property is threatened is confronted with a no-win situation: either kill the species to protect the property and face criminal fines and imprisonment, or tolerate the species' encroachment and suffer uncompensated property loss. Neither possibility is attractive.

Yet simply carving out a defense-of-property defense to ESA prosecutions would not be a complete solution either. Liability under the ESA deters individuals from interfering with endangered species. A defense-of-property defense may indeed recognize the individual's interest, but it goes too far in the other direction-it compromises the public's interest in species preservation by granting private citizens a correlative freedom (absent wilfulness, malice, and the like) to kill endangered species with near impunity. In addition to the considerable increase in litigation costs attendant to substantiating a defense-of-property defense, such a rule potentially devastates the goal of species preservation. The public cares only that endangered species continue to live, not that the killing of species is justified.

The solution to the dilemma posed by the conflict between the public interest, as embodied in the ESA, and the private citizen's interest in property preservation, lies beyond the ken of criminal law. Either allowing or disallowing a defense-of-property defense to ESA prosecutions arbitrarily elevates either private or public interests, respectively. Neither rule simultaneously satisfies both interests. A legal rule respecting both public and private interests is clearly preferable to a rule that necessarily compromises one interest to satisfy the other.

The optimal rule, as explored below, can be achieved through use of the constitutional doctrine of takings. While the ESA's criminal penalties are necessary to deter unjustifiable poaching,

${ }^{25}$ See Carol M. Rose, Mahon Reconstructed: Why the Takings Issue is Still a Muddle, 57 S Cal L Rev 561, 583-84 (1984) ("The typical logrolling legislature will pass legislation benefiting some interests now and other interests later."). 
the ESA makes no allowance for farmers and ranchers who violate the ESA to preserve their property. Proper application of the Takings Clause, by compensating plaintiffs for losses brought about by endangered species, would render plaintiffs indifferent as between saving property ex ante-by violating the ESA-and receiving compensation ex post. The Takings Clause does not interfere with species preservation; rather, it more equitably distributes the ESA's costs among the citizenry. Compensation harmonizes private and public interests by protecting both property value and endangered species.

\section{The Supreme Court's Approach to Takings}

The framers of the Constitution anticipated that the exercise of governmental power would engender conflicts between public and private interests. They undoubtedly believed that private citizens should not have absolute power to block public objectives; nor should the government, in the public's name, have the power simply to condemn private property. The Constitution provides subsequent legislative and judicial bodies with a means of reconciling the competing problems of species extinction and private property loss: the Takings Clause of the Fifth Amendment. This Section examines the historical pedigree of the clause and sketches the modern Court's bifurcated approach to takings claims.

\section{A. General Takings Clause Jurisprudence}

Over thirty years ago, the Supreme Court declared that the Takings Clause was "designed to bar Government from forcing some people to bear public burdens which, in all fairness and justice, should be borne by the public as a whole." ${ }^{26}$ The Clause, according to the Court, presumes that the challenged governmental regulation has a valid public purpose, but requires that the government compensate those individuals upon whom a disproportionately large burden of the regulation falls. ${ }^{27}$ The Takings Clause

${ }^{28}$ Armstrong $v$ United States, 364 US 40, 49 (1960). The Supreme Court has consistently affirmed this principle. First English Evangelical Lutheran Church $v$ Los Angeles County, 482 US 304, 318-19 (1987); Agins v Tiburon, 447 US 255, 260 (1980); Pennsylvania Coal Co. v Mahon, 260 US 393, 416 (1922); Monongahela Navigation Co. $v$ United States, 148 US 312,325 (1893).

${ }_{27}$ See First English Evangelical Lutheran Church, 482 US at 315 (The Fifth Amendment "is designed not to limit the governmental interference with property rights per se, but rather to secure compensation in the event of otherwise proper interference amounting to a taking.") (emphasis in original). But see Frank I. Michelman, Property, Utility, and Fairness: Comments on the Ethical Foundations of "Just Compensation" Law, 80 Harv L 
does not direct courts to invalidate legislation on the grounds that the legislation has disproportionate impact; it requires only that compensation be paid. ${ }^{28}$ The legislation remains valid and effective.

The legislative history of the Takings Clause is sparse at best. Despite the paucity of common law support and legislative materials, some historical sources have been identified to explain the drafters' motivations for including the Clause. Among them, seventeenth-century philosopher and theorist Hugo Grotius, upon whose ideas the framers drew, firmly believed in the sovereign's power to usurp the ownership rights of private citizens. ${ }^{2 \theta}$ This power to usurp, however, was tempered by an obligation to compensate: "A king may ... deprive his subjects of their right . . . by virtue of the eminent domain power[, but only] for some public advantage, and then the subject ought to receive, if possible, a just satisfaction for the loss he suffers, out of the common stock." ${ }^{30}$ Such writings may have influenced the inclusion of the Takings Clause in the Constitution. $^{31}$ Nevertheless, the historical sources that potentially contributed to the Takings Clause may be so irrelevant that the Supreme Court has never resorted to them in a takings case..$^{32}$

The Takings Clause arguably embodies the idea that the public has a mechanism to compel private interests to adhere to the public's needs, while establishing a correlative public duty to compensate for private property loss engendered by public action. The question of whether property has been taken "necessarily requires a weighing of private and public interests." ${ }^{33}$ If a taking is found, the legislation stands but compensation is due. Plaintiffs in takings cases assert only the government's duty to ameliorate the inequitable financial burdens imposed by the regulation..$^{34}$

Rev 1165, 1178 (1967) ("to insist on full compensation to every interest which is disproportionately burdened by a social measure dictated by efficiency would be to call a halt to the collective pursuit of efficiency").

${ }^{28}$ See Nollan v California Coastal Comm'n, 483 US 825, 831 (1987) ("one of the principal uses of the eminent domain power is to assure that the government be able to require [compliance with its regulations], so long as'it pays for them").

${ }^{29}$ Joseph L. Sax, Takings and the Police Power, 74 Yale L J 36, 54 (1964), citing Hugo Grotius, De Jure Belli et Pacis Bk 2, ch 14, §§ 7-8 (1625).

${ }^{30} \mathrm{Id}$, citing Grotius, De Jure Belli et Pacis at $\S 7$.

31 William B. Stoebuck, Nontrespassory Takings in Eminent Domain 12-15 (Michie, 1977).

${ }^{32}$ Richard A. Epstein, Takings: Private Property and the Power of Eminent Domain 29 (Harvard, 1985).

${ }^{33}$ Agins, 447 US at 261.

34 The form of such amelioration usually involves a corrective transfer payment from the public to the injured plaintiffs who have absorbed financial burdens disproportionate to 
Like the theorists that have come before, the Supreme Court has often considered what types of governmental actions effect a taking of private property, but has yet to establish a unified theory. Instead, the Court has developed a dual approach to takings based on the nature of the government's challenged action: per se physical takings and regulatory takings. These two strands of takings law are examined below.

\section{B. Per Se Takings: The Rule of Loretto}

The Supreme Court normally engages in "essentially ad hoc, factual inquiries" when analyzing possible takings, and balances competing public and private interests. ${ }^{35}$ The Supreme Court has declared that "a permanent physical occupation authorized by government is a taking without regard to the public interests that it may serve." ${ }^{36}$ By so holding, the Court established a narrow per se rule of compensation applicable to physical takings cases. The inquiry is framed to reflect a central concern for plaintiffs' property, rather than the government's legitimate regulatory goals. ${ }^{37}$

Unfortunately, the Court has declined to offer specific parameters for its per se rule. Potential litigants have been left wondering what such terms as "permanent" and "physical" mean. In Loretto $v$ Teleprompter Manhattan CATV Corp., the Court considered a New York law that prevented landlords from interfering with the installation of cable television facilities on their property. ${ }^{38}$ The Court held that the installation of two silver boxes and some cable wire occupying approximately $1 \frac{112}{2}$ cubic feet of space by employees of a private cable company effected a taking. ${ }^{39}$ By "permanent," the Loretto Court noted that "[s]o long as the property remains residential and a CATV company wishes to retain the installation, the landlord must permit it." termined by a government entity, but may hinge on the actions of

those imposed on the public at large. The ex post correction requires the government to pay the plaintiff the monetary equivalent of the precise amount of loss suffered.

ss Penn Central Transp. Co. $v$ New York City, 438 US 104, 124 (1978); Connolly $v$ Pension Benefit Guaranty Corp., 475 US 211, 224 (1986) (eschewing "any set formula" for identifying a taking). See also Richard A. Epstein, Takings: Descent and Resurrection, 1987 S Ct Rev 1, 4, suggesting that much of the confusion emanates from the Supreme Court's refusal "to give the Takings Clause the natural reading that its text suggests."

s6 Loretto v Teleprompter Manhattan CATV Corp., 458 US 419, 426 (1982).

s7 Id at $435-36$.

ss Id at 423, considering NY Exec Law $\$ 828(1)$ (McKinney Supp 1981-82).

ss Loretto, 458 US at $438 \mathrm{n} 16$.

40 Id at 439. 
a party external and indifferent to the litigation between the plaintiff and the government.41 By "physical," the Court noted that "whether the [cable] installation is a taking does not depend on whether the volume of space it occupies is bigger than a breadbox."

The Court expanded on these interpretations in Nollan $v$ California Coastal Comm'n.43 That case involved the issuance of a construction permit conditioned upon the granting of a public easement across the owners' beachfront property. ${ }^{44}$ The Court affirmed Loretto's rule that a per se taking occurs when the government mandates that individuals tolerate non-governmental thirdparty intrusions. ${ }^{45}$ The Court found that a "permanent physical occupation" of property occurs when "individuals are given a permanent and continuous right to pass to and fro ... . even though no particular individual is permitted to station himself permanently on the premises." ${ }^{\text {"6 }}$ Nollan establishes that the permanence requirement in Loretto's per se test does not require permanence as such; it requires only a continuing possibility that plaintiff's property may be traversed. ${ }^{47}$

The Supreme Court has announced and followed a rule requiring compensation for physical occupations of a plaintiff's property brought about by the government. The occupation itself need not be performed by the government. ${ }^{48}$ Plaintiffs who suffer permanent property loss pursuant to non-governmental third-party physical occupations are equally entitled to per se compensation, provided that the occupation flows from a governmental regulation.

\footnotetext{
41 Indeed, the Court noted that such occupation is worse when perpetrated by a stranger because the owner has "no control over the timing, extent, or nature of the invasion." Id at 436 .

42 Id at $438 \mathrm{n} 16$.

4343 US 825 (1987).

4 Id at 828-29.

45 Id at 831-32. See also Hall v City of Santa Barbara, 833 F2d 1270, 1277 (9th Cir 1987) (compensable taking found under per se rule where physical occupation was by tenants of mobile home park rather than by City of Santa Barbara).

46 Nollan, 483 US at 832.

47 Id. Compare PruneYard Shopping Center v Robins, 447 US 74 (1980) (state constitutional provision, construed to permit individuals to exercise free speech on the property of a privately owned shopping center, did not amount to an unconstitutional taking of shopping center owner's property, because plaintiff's inability to exclude did not impair the use or economic value of the shopping center).

48 Loretto, 458 US at 432 n 9 (sufficient that occupant is "authorized by the State").
} 


\section{Regulatory Takings}

The per se rule of Loretto is confined to the narrow area of a governmentally-authorized permanent and physical occupation of private property. More generally, "[ $t]$ he total destruction by the Government of all value of ... compensable property[] has every possible element of a Fifth Amendment 'taking' and is not a mere incidence of a valid regulatory measure." 49 The Supreme Court admits to no " 'set formula' for determining when 'justice and fairness' require that economic injuries caused by public action be compensated by the government, rather than remain disproportionately concentrated on a few persons." siders include: (1) the extent to which the regulation interferes with the claimant's "distinct investment-backed expectations"; 51 (2) the character of the government action (e.g., physical invasion versus public program that merely adjusts the "benefits and burdens of economic life to promote the common good"); ;2 and (3) the economic impact of the regulation on the claimant. ${ }^{.3}$

For example, in Penn Central Transp. Co. $v$ New York City, ${ }^{54}$ the Court held that New York City's Landmarks Preservation Law $^{55}$ did not constitute a taking of Penn Central's property by prohibiting the railroad from erecting a 55-story building on top of Grand Central Terminal. Penn Central had alleged that the law effectively "took" its property by depriving it of considerable revenues that would flow from the proposed building. ${ }^{68}$ In rejecting Penn Central's takings claim, the Court found it significant that plaintiffs "may [not] establish a 'taking' simply by showing that they have been denied the ability to exploit a property interest that they heretofore had believed was available." Court focused on the Terminal's present use. ${ }^{\mathrm{s} 8}$ As long as New

4 Armstrong, 364 US at 48.

so Penn Central, 438 US at 124.

s1 Id. For the proposition that the "investment-backed opportunities" inquiry is irrelevant to determining whether or not a taking has occurred, see Epstein, Takings at 65 (cited in note 32 ).

${ }^{32}$ Penn Central, 438 US at 124.

s3 Id.

s4 438 US 104 (1978).

ss NYC Admin Code, ch 8-A, § 205-1.0 et seq (1976).

ss 438 US at $119-20$.

s7 Id at 130. But see Boom Co. v Patterson, 98 US 403, 408 (1878) (Fifth Amendment applies with "reference to the uses for which the property is suitable, having regard to the existing business or wants of the community, or such as may be reasonably expected in the immediate future") (emphasis added).

ss 438 US at 135. 
York City's regulation did not physically invade Penn Central's property or its "primary expectation" of profitability"59-the present use of Grand Central Terminal-the Court was satisfied that Penn Central enjoyed a reasonable return on its investment and no taking had occurred. Had the Landmark Law required that Penn Central allow a wrecking company to destroy a fraction of Grand Central Terminal, the takings issue would have been far more compelling. Indeed, New York City conceded that relief would be warranted if the Landmark Law actually resulted in significant economic hardship to Grand Central Terminal. ${ }^{\text {o }}$

Similarly, the Court refused to find a taking in a rent control ordinance in Pennell $v$ San Jose. ${ }^{61}$ The ordinance allowed hearing officers to set rent increases below an otherwise "reasonable" amount if necessary to avoid possible "hardship to a tenant." ${ }^{62} \mathrm{Ab}$ sent any evidence that the tenant hardship ordinance had "in fact ever been relied upon by a Hearing Officer to reduce a rent" unreasonably, the Court held that the takings claim was premature. ${ }^{63}$ The Pennell Court treated the ordinance as merely creating the potential for a decrease in landlord revenues, while leaving open the question of whether an actual decrease in landlord revenues would constitute a compensable taking.

All regulations affect citizens' economic status. ${ }^{64}$ The Supreme Court has construed purely regulatory takings-property loss occasioned by a legislative enactment with no corresponding physical invasion-more narrowly than per se takings. ${ }^{65}$ The Takings Clause renders compensable only those regulations that result in

s9 Id at 136.

60 Id at $138 \mathrm{n} 36$.

61 485 US 1, 10 (1988). Compare Property Owners Ass'n v North Bergen, 74 NJ 327, 378 A2d 25, 31 (1977) ("A legislative category of economically needy senior citizens is sound, proper and sustainable as a rational classification. But compelled subsidization by landlords or by tenants who happen to live in an apartment building with senior citizens is an improper and unconstitutional method of solving the problem.").

${ }^{62}$ Pennell, 485 US at 5-6.

${ }^{83}$ Id at 9-10.

64 See id at 22 (Scalia dissenting); Pennsylvania Coal Co. v Mahon, 260 US 393, 413 (1922).

${ }^{8}$ PruneYard Shopping Center, 447 US at 82-85; Agins, 447 US at 260-63 (restrictive zoning ordinances did not effect a compensable taking where fundamental attributes of ownership not extinguished); Andrus v Allard, 444 US 51, 64-68 (1979) (prohibition of sale of bird parts protected by the Eagle Protection Act, 16 USC § 668, did not effect a compensable taking); United States v Central Eureka Mining Co., 357 US 155, 165-69 (1958) (War Production Board order requiring non-essential gold mines to cease operations did not constitute a compensable taking because temporary and the government did not accupy the mines). 
readily manifested and nearly complete property loss. Satisfaction of this standard, however, is by no means impossible. ${ }^{66}$ The determination of whether these conditions are met, therefore, turns on how broadly courts define the property taken. ${ }^{67}$

\section{Applying the Takings Analysis to the ESA}

Contrary to the Christy court's conclusion, current takings jurisprudence provides a basis for recovery by ESA plaintiffs. While the ESA is most appropriately viewed as a physical taking, this Section also examines the ESA through a regulatory lens and concludes the same: compensation is due.

\section{A. The Per Se Approach}

The ESA takings scenario involves a direct physical invasion by an endangered species onto the property of a private citizen.

\footnotetext{
6s See Hodel v Irving, 481 US 704, 712-18 (1987) (Indian Land Consolidation Act, 25 USC $\S 2206$, effected a regulatory taking by depriving plaintiffs of right to devise property); United States $v$ Kansas City Ins. Co., 339 US 799, 809-12 (1950) (compensable taking found where government construction of dam destroyed the agricultural value of part of plaintiff's land); and Mahon, 260 US at 412-16 (regulation restricting mining of coal to such an extent as to make further mining "commercially impracticable" effected a compensable taking).

${ }^{67}$ There is a strong argument that the distinction between per se and regulatory takings is unprincipled and should be dissolved. The difference rests on an outmoded physical/ non-physical distinction concerning the impairment of property interests in the modern regulatory state. The Court itself has wrestled with the distinction for over a century. See Pumpelly v Green Bay Co., 80 US 166, 177-78 (1871). Certainly, the nature of the government's action is relevant to an assessment of the regulation's validity; but validity is an inquiry distinct from compensation. The nature of the government's action is independent of the injury wrought upon property owners. Keystone Bituminous Coal Ass'n v DeBenedictis, 480 US 470, 516 (1987) (Rehnquist dissenting). The takings plaintiff is indifferent to whether the judiciary labels the property loss a "physical occupation," "regulatory taking," or "Fred." The plaintiff is interested only in receiving compensation for the damage done.

The artificiality of the distinction is evidenced by United States $v$ Causby, 328 US 256 (1948). There, the Court found that frequent low-altitude flights of military aircraft over plaintiff's land effected a taking of plaintiff's property when the loud sound emitted by the aircraft frightened plaintiff's chickens, provoking them to fly fatally into the walls of their chicken house. Id at 262 . While never coming into physical contact with plaintiff's property, the aircraft interfered with plaintiff's enjoyment of property "as complete[ly] as if the United States had entered upon the surface of the land and taken exclusive possession of it." Id at 261. The Court was concerned with the effect of the government's action, not whether such action was direct or regulatory in nature.

Justices Rehnquist and Blackmun, while endorsing opposing results, have both advanced strong arguments for dissolving the distinction between per se and regulatory takings. Keystone, 480 US at 516 (Rehnquist dissenting) (advocating a purely physical test); Loretto, 458 US at 447 (Blackmun dissenting) (advocating a purely regulatory test). The Court as a whole, however, continues to cling to the two takings strands. For further examination of this topic, see Epstein, Takings at 49-50 (cited in note 32); Lawrence Blume and Daniel L. Rubinfeld, Compensation for Takings: An Economic Analysis, $70 \mathrm{Cal} \mathrm{L} \mathrm{Rev} \mathrm{569,}$ 574-75 (1984).
} 
This physical invasion implicates the Supreme Court's per se rule of Takings Clause compensation. Loretto and Nollan demonstrate that the actual physical invasion that effects the taking need not be perpetrated by governmental actors. The government owes Takings Clause compensation because it is the government's statute or other regulation that paves the way for the third party's uncontested physical invasion. Endangered species' predatory encroachments that are made possible by the ESA implicate constitutional concerns and require governmental compensation payments to injured citizens.

1. The ESA is "government in action."

The Takings Clause is triggered, of course, only by government action. At least one justice believes that the ESA may be such a trigger:

[A] government edict barring one from resisting the loss of his property is the constitutional equivalent of an edict taking such property in the first place. Thus if the government decided (in lieu of the food stamp program) to enact a law barring grocery store owners from 'harassing, harming, or pursuing' people who wish to take food off grocery shelves without paying for it, such a law might well be suspect under the Fifth Amendment. For similar reasons, the ESA may be suspect. ${ }^{68}$

In terms of the effect upon a person deprived of property, there is no difference between property loss caused by a government actor and that caused by an actor authorized by the government to take.

The Christy court refused to apply Loretto's per se test, concluding that the grizzly bear's taking of plaintiff's property could not be attributed to "government agents." result because "[ $t]$ he federal government does not 'own' the wild animals it protects, nor does the government control the conduct of such animals." Bo But Loretto and Nollan clearly demonstrate that government actors need not effect the physical intrusion for there to be a compensable taking. ${ }^{71}$ The ESA, by stifling preventive efforts, works a compensable taking through the physically intrusive and destructive actions of governmentally protected species.

\footnotetext{
${ }^{68}$ Christy, 490 US at 1115-16 (White dissenting from denial of cert).

$6987 \mathrm{~F} 2 \mathrm{~d}$ at 1334 .

70 Id at 1335 .

${ }^{71}$ Loretto, 458 US at 421 ; Nollan, 483 US at 832.
} 
The similarity between Loretto and the ESA takings scenario is striking. In both, government statutes required plaintiffs to abstain from interfering with non-governmental third-party permanent occupations of plaintiffs' property. Loretto unequivocally established that "[a] permanent physical occupation authorized by state law is a taking without regard to whether the State, or instead a party authorized by the State, is the occupant." ${ }^{2}$ Both Loretto and Nollan support the view that a per se taking occurs when the government authorizes physical occupation by non-governmental actors. The ESA is precisely the kind of statute contemplated by Loretto. Courts should decide ESA takings challenges under the per se rule.

Even so, the Christy court mistakenly assumed that the government's lack of an ownership relationship to wild animals absolved it from liability for the animals' damage. Ownership is not a prerequisite for liability. Takings analysis does not require that the perpetrating endangered species be owned by the government-surely the government owned neither the cable company employees in Loretto nor the random passersby in Nollan. However, the case for Takings Clause compensation is even stronger under the ESA precisely because the government does maintain a type of controlling relationship with endangered species: the government owns wild animals in a trustee capacity for the benefit of the citizenry.

In Toomer $v$ Witsell, the Court noted that "fish and game are the common property of all citizens of the governmental unit and that the government, as a sort of trustee, exercises this 'ownership' for the benefit of its citizens."73 The government's power to control and regulate wild animals "is to be exercised, like all powers of government, as a trust for the benefit of the people, and not as a prerogative for the advantage of the government, as distinct from the people ...." "74

The existence of a trustee relationship to wild animals does not absolve the government of responsibility for the damaging actions of wild animals. Courts have imposed liability upon trustees (1872).

72458 US at 433 n 9 (emphasis added), citing Pumpelly v Green Bay Co., 80 US 166

73334 US 385, 399 (1948). See also Patsone v Pennsylvania, 232 US 138, 145-46 (1914) (the government may preserve wild animals for the benefit of its citizens).

74 Geer $v$ Connecticut, 161 US 519, 529 (1896), overruled on other grounds by Hughes $v$ Oklahoma, 441 US 322 (1979). 
for the damage wrought by the protected person or property. For instance, trustees are liable for torts occasioned by the estate over which they preside. ${ }^{75}$ If there is a nuisance on a piece of property held in trust, the trustee is civilly liable for damages to be paid out of the estate. ${ }^{76}$

The trustee relationship should therefore be understood to impose affirmative duties on the government to monitor the actions of endangered species and to impose liability for damage done. The government does not maintain the same relationship with endangered species protected by the ESA that it does with other wild animals. Through the ESA, the government has affirmatively shouldered the burden of managing and sustaining endangered species. The government's responsibility for the damaging acts of species protected by the ESA-especially when the damage could have been prevented but for the ESA-is heightened.

The lack of governmental responsibility for injury inflicted by "ordinary" wild animals does not suggest that the government should similarly avoid responsibility for injury inflicted by animals protected by the ESA. At common law, individuals could protect their property from encroachments by wild animals and successfully plead defense-of-property defenses to prosecutions under game laws. ${ }^{77}$ The ESA, however, fails to provide the defense-ofproperty defense, thereby leaving property owners completely vulnerable to the destructive encroachments of protected species. ${ }^{78}$ To further the public goal of species preservation, the government has used the ESA to strip citizens of a widely recognized common law defense. The government must fill the void that the ESA creates by accepting responsibility for the torts of protected species and paying just compensation for damage done.

The Christy court mistakenly concluded that the ESA did not "force" the plaintiff to shoulder a disproportionate amount of the

${ }^{75}$ See, for example, First Natl Trust \& Sav. Bank v Industrial Accident Comm'n, 213 Cal 322, 2 P2d 347, 348-49 (1931) (executor of testator's business liable for compensation for employee's injury); Gardiner $v$ Rogers, 267 Mass 274, 166 NE 763, 764 (1929) (trustee liable for defective condition of trust premises); Schmidt v Kellner, 307 Ill 331, 138 NE 604, 60608 (1923) (trustee liable for death occasioned by collapse of water tank on trust premises when trustee has title and right of possession).

${ }^{76}$ See O'Malley o Gerth, 67 NJ L 610, 52 A 563 (1902) (trustees liable for failure to repair hole in sidewalk on trust premises). See also Pruitt v Allied Chemical Corp., $523 \mathrm{~F}$ Supp 975, 978 (E D Va 1981) (commercial fishermen may recover from polluters of a bay because the fishermen have a constructive property interest).

77 See text and sources cited at notes $17-20$.

${ }^{78}$ For discussion of plaintiff's ability to fence out protected species, see text at notes 82-87. 
burden of species preservation. ${ }^{79}$ To be sure, the ESA does not impose on individuals a quota of animals that must be provided in order to feed protected species. Yet, the term "force" is not so limited. Plaintiffs are forced to bear a disproportionate share of the cost of species preservation by being prevented from recovering for destroyed property. ${ }^{80}$ If plaintiffs were compensated for destruction of their property, then plaintiffs would contribute to the goal of species preservation on a level proportionately equal to that of the rest of society. Plaintiffs' tax payments would be the sole source of their mandatory contribution to the preservation of endangered species. By preventing plaintiffs from protecting their property, the ESA imposes two costs on plaintiffs-tax dollars and property loss-whereas all other citizens pay only once.

\section{The analytic foundations of per se takings.}

The Loretto Court offered three policy reasons for adopting the per se rule. First, when confronted by a physical invasion, the property owner "has no right to possess the occupied space himself, and also has no power to exclude the occupier from possession."81 The protected species effectively usurps the plaintiff's right to possess and exclude by killing the plaintiff's domesticated animals or otherwise destroying plaintiff's property. Worse, the ESA prevents the plaintiff from even interfering with this process in almost any way. While ranchers can ordinarily erect fences to keep out unwanted intruders, the ESA may, in fact, prohibit individuals from fencing out protected species. The ESA's prohibition against harassing, harming, or trapping endangered species, ${ }^{82}$ has been broadly construed to prohibit acts "that significantly disrupt[] normal behavior patterns of the endangered animal" or "that result[] in significant environmental modification or degradation of the endangered animal's habitat." ${ }^{\text {"8s }}$ If fencing out prevents endangered species from obtaining food necessary for their survival, thereby significantly disrupting their habitat, then it may not be a viable option under the ESA's express terms. Moreover, if plaintiff's animals graze on public lands, then plaintiff has no right

\footnotetext{
$79857 \mathrm{~F} 2 \mathrm{~d}$ at 1335.

so Justice Scalia's dissent in Pennell, 485 US at 21-22, emphasizes that regulated entities can constitutionally be forced to bear a disproportionate burden only when they are the "cause" of the harm that the regulation seeks to eliminate.

8148 US at 435.

:2 16 USC $\$ \S 1538(\mathrm{a})(1)(\mathrm{B})$ and 1532(19).

ss Palila v Hawaii Dept. of Land \& Nat. Resources, 639 F2d 495, 497 (9th Cir 1981) (quoting $50 \mathrm{CFR} \S 17.3(\mathrm{c})$ ).
} 
to fence them in at all. ${ }^{84}$ Because many ranchers permit their domesticated animals to graze on public lands, ${ }^{85}$ fencing out will often be a practical impossibility.

Further, takings issues may again be implicated if plaintiffs are forced to incur the considerable costs of erecting fences to comply with the ESA. As a practical matter, the cost of the fences may exceed the cost of the property that would otherwise be lost. It is simply not cost-effective to fence in enormous amounts of pasture land. Even if fencing were allowed, however, it would only forestall-but not eliminate-takings allegations. Once the protected species breaches the fence, the rancher will again be helpless when the proverbial grizzly finally arrives at the sheep. ${ }^{86}$ Indeed, fences may be unable to keep out the very predatory species about which farmers and ranchers are most concerned. Eventually, the taking here would be both physical and permanent.

The second policy reason underpinning Loretto is that "the permanent physical occupation of property forever denies the owner any power to control the use of the property." the plaintiff, confronted by the ravaged remains of what was once a domesticated animal, has been permanently deprived of the power to fully control the animal. After the taking, the plaintiff's control over the animal reduces to the disposition of the dead animal's carcass. The plaintiff has been permanently denied the ability to exercise full control over the lost animal. Further, as in Nollan, the plaintiff suffers permanent property loss from the enduring and continuous threat of third-party future encroachments.

The third reason for the Loretto per se rule flows from the second; the third-party physical usurpation deprives a successor in interest the ability to use the property. ${ }^{88}$ The animal's decaying carcass is as worthless to a successor in interest as it is to the plaintiff. There is little market for it. Even worse, the economic loss occasioned by the death of the animal is aggravated by costs of disposition borne by the plaintiff.

\section{B. The Regulatory Approach}

As suggested, ESA takings challenges fall squarely within Loretto's per se rule of compensation. The government implicitly

s4 Camfield v United States, 167 US 518, 528 (1897).

${ }^{85}$ Michael J. Bean, The Evolution of National Wildlife Law 150-51 (Praeger, 1983).

${ }^{86}$ Indeed, the bear may be even hungrier after working up an appetite by breaking through the fence.

858 US at 436.

${ }^{88}$ Id. 
authorizes third parties-protected species-to intrude upon and damage plaintiff's property. The fact that here such authorization is incidental to the regulation, while in Loretto and Nollan it was part of the regulation's express purpose, should make no difference-private individuals are still forced to allow the intrusion. But even if courts err-as did the Christy court-by refusing to analyze ESA takings challenges under the per se rule, the alternative regulatory takings test still requires compensation. The facts posed by ESA cases satisfy the three criteria laid out in Penn Central, as well as general regulatory takings concerns. ${ }^{89}$

First, the ESA interferes substantially with "distinct investment-backed expectations." Unlike the prospective property loss that the Penn Central Court held insufficient to effect a taking, ${ }^{91}$ takings under the ESA result in immediate and identifiable loss. When a particular animal is killed or certain crops are destroyed, it is easy to assess the economic loss incurred. ${ }^{92}$ Discrete animals and crops have readily discernible market values independent of their respective values as part of a larger whole. The property loss is best understood and valued as the loss of a particular animal, not as some diminution in the overall value of the herd from which the animal was taken. Even when analyzed as a regulatory taking, plaintiffs are entitled to compensation because the taking has destroyed $100 \%$ of the relevant property value. ${ }^{93}$ No alternative economic use remains.

Second, the character of the government action deprives citizens of their right to exclude. In Kaiser Aetna v United States, the Court considered a regulation that converted a privately owned marina into a public aquatic park..$^{94}$ The Court ordered the government to pay compensation to the developers of the private marina, holding that the government's intended navigational servitude

so The Supreme Court described its Penn Central decision as containing "one of the most complete discussions of the Takings Clause." Loretto, 458 US at 432.

20 Penn Central, 438 US at 124.

91 Id at 130.

22 It is not, however, always obvious precisely how the property was damaged. This inquiry is essential because the government is responsible only for compensatory loss that would not have occurred but for the ESA. The difficulty may be resolved by the adoption of a federal system mirroring that of Wyoming. See note 109.

os See Armstrong $v$ United States, 364 US 40 (1960) (government acquisition of title to uncompleted boats upon default by shipbuilder effected compensable taking of liens); Mahon, 260 US 393 (regulation restricting mining of coal to such an extent as to make the mining "commercially impracticable" effected a compensable taking).

or 444 US 164, 180 (1979). 
went beyond an exercise of "regulatory power" that imposed only "insubstantial devaluation" on plaintiff"s private property. ${ }^{95}$ The decision was driven by a central concern for the property owner's right to exclude, which the Court declared "a fundamental element of the property right." ${ }^{86}$ Thus, the government may not usurp a citizen's right to exclude others from that citizen's private property without paying compensation. ${ }^{97}$

As the challenged regulation in Kaiser Aetna compelled the admission of strangers into an otherwise private marina, the ESA compels-albeit indirectly-the admission of strangers onto private land. Worse, the ESA permits these strangers to ravage the private property on which they trespass. That the strangers in Kaiser Aetna are human while those under the ESA are animals is not a principled basis on which to distinguish a legal rule. An owner's right to exclude encompasses the exclusion of any encroachment, whether human, animal, or otherwise. ${ }^{88}$ By prohibiting any action that interferes with protected species, the ESA significantly decreases an owner's abilities to exclude unwanted animals from the owner's property. The property deprivation here mirrors the deprivation in Kaiser Aetna that led the Court to find a compensable taking. The ESA plaintiff is entitled to compensation for an infringement of this right.

Third, the regulatory takings test focuses on the degree of loss imposed on plaintiff's property. ${ }^{99}$ Defining the property taken should thus be a central inquiry. ${ }^{100}$ In Mountain States Legal Foundation $v$ Hodel, ${ }^{101}$ plaintiffs sought compensation for forage damage inflicted by governmentally protected wild horses. The court did not deny that the Wild Free-Roaming Horses and Burros Act deprived plaintiffs of significant property value, but the court refused to find a compensable taking because considerable value

${ }^{\text {os }}$ Id.

${ }^{98}$ Id. The Loretto Court was also concerned about protecting citizens from "a special kind of injury when a stranger directly invades and occupies the owner's property." 458 US at 436 (emphasis in original). See also Nollan, 483 US at 831.

97 See also Fallini v Hodel, 725 F Supp 1113, 1123 (D Nev 1989).

${ }^{88}$ Plaintiffs may sue in equity to enjoin structural trespass or other physical encroachments on property. Annotation, Mandatory Injunction to Compel Removal of Encroachments by Adjoining Landowner, 28 ALR2d 679, 685 (1953).

${ }^{80}$ Loretto, 458 US at 453 (Blackmun dissenting) (takings inquiry should consider whether the deprivation imposed by the government's regulation severely interferes with an owner's alternative property uses).

100 See Sax, 74 Yale $\mathrm{L} J$ at 60 (cited in note 29).

101799 F2d 1423 (10th Cir 1986) (en banc). 
remained. ${ }^{102}$ It viewed the damage as relatively insubstantial because plaintiffs still enjoyed considerable value from their remaining property.

The Mountain States court improperly analyzed the takings issue. A taking should be determined by what the state has taken, not by what the owner has retained. ${ }^{103}$ Even if the takings claim were considered within the context of some diminution in the value of the whole, a taking may still be found. Small losses of property have been held compensable. In Keystone Bituminous Coal Ass'n $v$ DeBenedictis, the Court noted that the government may not appropriate even "relatively small amounts of private property" unless it pays compensation. ${ }^{104}$

Indeed, the ESA destroys private property to the same extent as if the government had taken by direct appropriation. It is particularly instructive that the plaintiff in United States $v$ Causby $y^{105}$ did not suffer loss as a direct result of the government action. Rather, the chickens, while frightened by the sounds of military aircraft, flew into their coop's walls of their own volition. The chickens' independent acts-flying into walls-resulted in the property loss. No government agent actually threw the chickens against the walls. Nor did the government force the chickens into flight. Yet, the Causby Court held that the Takings Clause required the government to pay compensation. ${ }^{106}$

Similarly, the endangered species that invade plaintiff's property do not act at the behest of governmental actors. Nor does the ESA effectuate private property loss by enabling government agents to enter onto plaintiff's property and appropriate plaintiff's animals for consumption by endangered species. The taking is effected by the actions of the endangered animals themselves. Causby demonstrates that property loss occasioned by the acts of animals, but engendered by government regulation, requires compensation under the Takings Clause.

It is the ESA's unequal distribution of burdens, not the policy objectives of the statute, that is troubling. The Takings Clause provides a clear and effective mechanism through which a regula-

${ }^{102}$ See id at 1430-31, citing Penn Central, 438 US at 130-31.

${ }^{103}$ Epstein, $1987 \mathrm{~S} \mathrm{Ct}$ Rev at 17 (cited in note 35).

104480 US at $499 \mathrm{n} 27$. See also Loretto, 458 US at 436 ("constitutional protection for the rights of private property cannot be made to depend on the size of the area permanently occupied"); Hodel v Irving, 481 US 704, 727 (1987) (Stevens concurring) ("The Fifth Amendment draws no distinction between grand larceny and petty larceny.").

${ }^{105} 328$ US 256 (1946). The facts of this case are discussed in note 67.

108 Id at 261-62. 
tion's de facto inequitable distribution of burdens may be corrected. Courts should not be reluctant to employ the Constitution's guarantee of compensation to correct the ESA's disproportionate impact.

\section{Incentive Effects of Granting Compensation to ESA Plaintiffs}

Application of the Takings Clause to predations by federally protected endangered species promotes the goal of species preservation. Plaintiffs will continue to be prevented from interfering with the endangered species. Indeed, with the expectation of receiving compensation, plaintiffs will have stronger incentives to comply with the ESA than they have today. At the same time, the government will be forced to internalize the costs attendant to species preservation, and decide how best to preserve endangered species within the parameters of the Constitution.

Endangered species, like all animals, need food. Grizzly bears happen to like sheep. In a zoo, the zookeepers must go out and purchase food for the animals and feed them. In the wild, however, the bears must get their food themselves. The ESA accommodates this by preventing ranchers from shooting grizzly bears when the bears feed upon the ranchers' sheep. While bears may be indifferent to this arrangement, the rancher is not. The current system is very efficient for the government. The bears secure the precise amount of sustenance they require-because they eat when and how much they want-and the government pays nothing. Compensating citizens for the property damage done in the process, however, would force the government to internalize the cost of species preservation $^{107}$ and could alter the government's chosen preservation method.

Absent a corresponding obligation to compensate, the ESA provides the government with some financial relief from its desire to provide for protected species. The government has, in effect, appropriated private citizens' animals and crops for its own use-preserving endangered species-by preventing citizens from interfering with the species' consumption or other activity. When a protected animal dines on a citizen's property, the government is relieved of the financial and administrative burden of providing that animal with food. ${ }^{108}$

\footnotetext{
107 See Ronald Coase, The Problem of Social Cost, 3 J L \& Econ 1 (1960).

${ }^{108}$ See, for example, Mountain States, 799 F2d at 1435 (Seth dissenting) ("The con-
} 
The ESA is a very efficient arrangement of food provision for endangered species. Congress instead could have established a system whereby park rangers appropriated farm animals and crops from ranchers and farmers and then fed them to endangered species. Obviously, the government would incur tremendous costs in salaries, payments for the food, transportation, and locating the endangered species at feeding time. In addition, the public would incur the costs of overbuying, or worse, underbuying food which might lead to species death. A regulation that sustains the species indirectly through a series of exchanges-from rancher, to government agent, to feeding ground for endangered species-requires a greater expenditure of public resources to provide for endangered species. Such added costs would constitute a waste of resources that could otherwise be allocated to more productive conservation measures. Society benefits from the regulatory regime under which species take the precise amount of privately owned food that they require at any given time. Therefore, the ESA is efficient. Yet, its efficiency does not excuse its constitutional infirmity.

The ESA's unconstitutionality is easily remedied by the payment of Takings Clause compensation to proper plaintiffs. Because the government will only compensate for damage that would not have occurred but for the ESA, such compensation will merely distribute the ESA's costs of species preservation more evenly throughout society. ${ }^{109}$ Therefore, introducing the compensation question into the analysis should not change society's preference for the ESA as the most efficient scheme for preserving endangered species. By enacting the ESA, the government has already declared that the public is willing to assume the economic burden associated with species preservation. The public should be willing and able to allocate public resources to the preservation of endangered species either by funding wildlife preserves or by compensating private landowners who feed the animals. By compensating ESA

sumption of privately owned forage was of course to support the [protected] horses for a public purpose. ... The Government has thus used and caused the consumption of plaintiffs' property for a public purpose.").

${ }^{109}$ A discussion of the methods of compensation is beyond the scope of this Comment. However, it will be relatively easy for property owners to demonstrate that they have been harmed by endangered species in a way that would not have occurred but for ESA's prohibitions. Instead of carrying a rifle, a rancher may carry a camera. Wyoming has implemented a successful compensation scheme that may serve as a model for a federal system. See Wyo Stat § 23-1-901 (1990). Wyoming's system provides a mechanism through which individuals may seek and obtain recovery for property loss inflicted by "big or trophy game animals." The system provides for individual claims for damages, investigation of the claims, appeals, arbitration and either a grant or denial of compensation. 
plaintiffs for their property losses, the government will internalize the costs of species preservation.

\section{ConcLusion}

This Comment neither suggests that the ESA be abolished nor contends that species preservation is an unworthy goal. Indeed, this Comment recognizes that the ESA is both an efficient and valid piece of legislation. As interpreted, however, the ESA is unconstitutional. Current ESA takings jurisprudence has ignored the purpose of the Takings Clause. The public is willing to assume the financial burden of furthering the goals embodied by the ESA. The mere happenstance that protected species occasionally choose to consume private rather than public property does not justify the imposition of the public's financial burden upon random injured individuals.

The Constitution mandates that public goals should not be furthered at the expense of a few private citizens. Yet, courts have ignored the plight of the private citizen in ESA cases while misplacing emphasis on the importance of the objectives to be served by the ESA. The importance of the ESA's objectives is conceptually distinct from the takings question. The Takings Clause requires compensation not only for injury occasioned by legislation of dubious public worth, but also for injury occasioned by legislation which, whether important or not, compels certain private citizens to shoulder disproportionate societal burdens. Courts have mistakenly conflated the ESA's valuable objectives with the compensation question. These courts readily concede that plaintiffs have been deprived of considerably more property than the general public. The only constitutionally sound response to plaintiffs' claims is to compensate them for their involuntary contributions to the goals of the ESA by making transfer payments from the public trust to plaintiffs' private and disproportionately depleted coffers. 